\title{
Pengaruh Struktur Modal dan Kemampulabaan Terhadap Return Saham Perusahaan Properti dan Real Estate Yang Terdaftar Di BEI Tahun 2013-2015
}

\author{
Wadudi Wibowo ${ }^{1}$ dan Ani Mekaniwati ${ }^{2}$ \\ Program Studi Manajemen, Fakultas Bisnis IBI Kesatuan \\ E-Mail: ${ }^{1}$ wadudi@ibik.ac.id, ${ }^{2}$ a.meka@ibik.ac.id
}

Submitted: APRIL 2020

Accepted: APRIL 2020

\begin{abstract}
This research is to acknowledge the influence of capital structure and profitability to the stock returns of the listed real estate and property companies in BEI on 2013-2015. This research consists of two independent variables regarding capital structure and profitability, and one dependent variable regarding stock returns. Data used is secondary data which could be accessed from www.idx.co.id. The hypothesis testing in this research uses data panel regression model. The results are: 1) positive \& significant results between DER towards capital returns 2) positive \& significant results between NPM towards capital returns. The contributions for potential investors, this research was hoped to increase the knowledges of financial information of the companies specialised in real estate \& properties sector. Also hoped to give good contributions to discussion on financial analysis particularly related with DER, NPM \& capital returns.
\end{abstract}

Keywords : capital structure, profitability, stock returns, and data panel regression

\begin{abstract}
ABSTRAK
Penelitian ini untuk mengetahui pengaruh struktur modal (DER) dan profitabilitas (NPM) terhadap return saham pada perusahaan properti dan real estate yang terdaftar di Bursa Efek Indonesia pada periode 2013-2015. Penelitian ini terdiri dari dua variabel independent mengenai struktur modal dan profitabilitas, dan satu variabel dependent mengenai return saham. Data yang digunakan adalah data sekunder yang di dapat di akses melalui www.idx.co.id. Pengujian hipotesis dalam penelitian ini menggunakan model regresi data panel. Hasil penelitian ini adalah : (1) ada pengaruh positif dan signifikan antara DER terhadap return saham. (2) ada pengaruh positif dan signifikan antaran NPM terhadap return saham. Kontribusi bagi calon investor, penelitian ini diharapkan menambah pengetahuan bagi para investor atas informasi keuangan perusahaan khususnya dalam sector properti dan real estate. Bagi penelitian selanjutnya, diharapkan dapat memberikan kontribusi yang baik terhadap pembahasan mengenai analisa keuangan khususnya yang terkait dengan DER, NPM dan Return Saham.
\end{abstract}

Kata kunci : struktur modal, kemampulabaan, return saham, regresi data panel

\section{PENDAHULUAN}

Persaingan dunia industri properti saat ini begitu keras, dilihat dari kondisi beberapa tahun kebelakang ini, dimana perusahaan properti sempat melonjak dan kemudian mengalami penurunan setiap tahunnya. Pada tahun 2011 R.M.A. Van Der Schaar,

JIMKES

Jurnal Ilmiah Manajemen Kesatuan Vol. 8 No. 1, 2020 pp. $19-28$
IBI Kesatuan IBI Kesatuan
ISSN $2337-7860$ E-ISSN $2721-169 \mathrm{X}$ 
Capital Structure and Profitability

20
Managing Director Indonesia Investments menyatakan bahwa pada umumnya harga properti residensial bertumbuh hampir 30\% per tahun antara 2011 dan 2013. Pertumbuhan yang kuat terjadi karena ekspansi perekonomian Indonesia yang subur. Belanja konsumen kelas menengah yang kuat membuat segmen bisnis hunian menjadi kontributor terbesar untuk pertumbuhan properti Indonesia yang mencakup sekitar 60\% dari total sektor properti (Indonesia Investment, 2016).

Pada tahun 2012 dan pertengahan pertama tahun 2013 sektor properti Indonesia bertumbuh cepat, maka pertumbuhan keuntungan para developer properti Indonesia melonjak tajam (dari 45 perusahaan properti yang terdaftar di Bursa Efek Indonesia pada tahun 2012, 26 perusahaan mencatat pertumbuhan laba bersih lebih dari 50\%) dan jelas harga properti Indonesia meningkat sejalan dengan itu. Pasar properti Indonesia naik tajam karena rendahnya tingkat suku bunga Bank Sentral. Antara Februari 2012 sampai pertengahan 2013, Bank Sentral Indonesia (Bank Indonesia) mempertahankan suku bunga acuannya (BI rate) pada $5,75 \%$, kebijakan suku bunga terendah dalam sejarah negara dengan ekonomi terbesar di Asia Tenggara ini (Indonesia Investment, 2016). Di pertengahan kedua tahun 2013, industri properti mulai mengalami penurunan pasar. Hal ini disebabkan karena Bank Indonesia menaikkan persyaratan uang muka minimum dan memotong pinjaman hipotek untuk kepemilikan rumah kedua (untuk mencegah peningkatan berlebihan dari pinjaman untuk hunian). Bank-bank juga dilarang memberikan pinjaman untuk properti-properti yang masih dalam proses pembangunan (untuk para pembeli hunian kedua atau lebih). Persyaratan uang muka yang lebih tinggi (atau rasio loan-to-value yang lebih rendah) untuk properti-properti berukuran lebih dari 70 meter persegi, persyaratan secara spesifik ditujukan untuk pasar menengah ke atas. Lalu adanya perubahan tingkat suku bunga Indonesia, setelah sentuh titik rendah dalam sejarah pada 5,75\% dari Februari 2012, Bank Indonesia secara bertahap, namun agresif, menaikkan BI rate antara Juni 2013 sampai November 2013 menjadi 7,50\% (Indonesia Investment, 2016).

Pada tahun 2014, industri properti masih melemah. Hal ini terjadi karena adanya tahun politik Indonesia (Indonesia mengadakan pemilihan legislatif dan presiden pada tengah 2014) menyebabkan ketidakjelasan politik dan karenanya timbul ketidakjelasan perekonomian juga. Menjelang pemilihan-pemilihan ini, para pengembang Indonesia cenderung menunda proyek-proyek baru (penundaan proyek-proyek properti juga merupakan dampak dari menurunnya pencairan pinjaman hipotek dan BI rate yang lebih tinggi). Indeks Harga Properti Hunian dari Bank Indonesia menurun 6,3\% di 2014. Penurunan terbesar untuk pertumbuhan properti dirasakan di wilayah Jakarta Bogor Depok Tangerang \& Bekasi (Jabodetabek). Hal ini juga merupakan akibat dari pasar properti Jakarta (dan juga pasar-pasar lainnya di kota-kota besar di Jawa seperti Surabaya dan Bandung) telah menjadi agak jenuh karena pembangunan properti besarbesaran di tahun-tahun sebelumnya (Indonesia Investment, 2016)

Pada tahun 2015, sebuah survei dari Bank Indonesia menunjukkan bahwa harga dan volume penjualan properti residensial masih menunjukkan perlambatan sepanjang kuartal IV-2015, sementara kalangan pengembang menilai perlambatan masih akan berlanjut sepanjang semester I tahun 2016. Bank Indonesia (BI) mengungkapkan harga properti residensial masih meneruskan tren perlambatan sejak awal 2015. Hasil dari penjualan di kuartal pertama tahun 2015 mencatat 26,6\% dibandingkan dengan 40,1\% di kuartal ke-4 tahun 2014. Sementara itu, tingkat pencairan pinjaman hipotek di bankbank untuk rumah dan apartemen di kuartal 1 tahun 2015 naik hanya 0,12\% dibandingkan kuartal sebelumnya. Di kuartal IV/2015 indeks harga properti residensial hanya tumbuh $0,73 \%$, lebih lambat dibandingkan kuartal III-2015 yang tumbuh $0,99 \%$. Perlambatan penjualan diduga karena kondisi perekonomian yang melambat sehingga berpengaruh pada penurunan permintaan terhadap properti residensial. Kenaikan harga bahan bangunan dan upah pekerja juga menjadi penyebab kenaikan harga rumah. Sedangkan dari sisi pasokan, hasil survei mengungkapkan bahwa adanya aturan loan to value terbaru yang mengharuskan jaminan tambahan dari pengembang dirasa sangat memberatkan aliran dana perusahaan. Sebagian besar responden berpendapat bahwa 
faktor utama yang dapat menghambat pertumbuhan bisnis properti adalah suku bunga KPR (20,92\%), uang muka rumah (20,04\%), kenaikan harga bahan bangunan $(17,48 \%)$, serta perizinan (16,13\%). (Bisnis Properti, 2016).

Dunia usaha properti menjadi semakin kompetitif sehingga menuntut perusahaan untuk mampu beradaptasi agar dapat unggul dalam persaingan. Usaha tersebut memerlukan modal yang sangat besar dan tepat, dan salah satu modal terbesar yang dapat diperoleh perusahaan yaitu dari investor atau pemegang saham melalui penanaman investasi. Tentu saja melalui penanaman investasi, para investor mengharapkan adanya return saham. Melihat hal ini, para investor mulai berhati-hati dalam menginvestasikan uangnya pada saham properti dikarenakan pertumbuhan pendapatan perusahaan properti yang sangat tinggi beberapa tahun terakhir kemudian menjadi turun. Kenaikan harga properti yang awalnya menarik investor spekulatif di sektor properti, sehingga harga naik lebih tinggi, pada akhirnya akan menurunkan daya beli konsumen akhir ( Kompasiana, 2013). Dan untuk properti yang tidak menghasilkan return yang baik, hal ini menyebabkan kebanyakan investor properti masih menunggu perkembangan kondisi ekonomi serta sangat sensitif terhadap wacana-wacana kebijakan baru pemerintah yang dinilai negatif bagi bisnis properti ( Bisnis.com, 2017)

Objek penelitian ini menggunakan perusahaan industri properti dan real estate yang terdaftar di Bursa Efek Indonesia. Penelitian ini didasari oleh adanya fenomena dalam dunia bisnis properti yang beberapa tahun belakangan mengalami penurunan pasar akibat munculnya kebijakan-kebijakan Bank Indonesia dan situasi politik di Indonesia, sedangkan untuk menjalankan suatu bisnis dibutuhkan modal yang besar yang bisa didapatkan dari penanaman modal investor yang tentu saja para investor menginginkan adanya return saham. Permasalahan utama penelitian ini adalah:

1. Apakah Debt to Equity Ratio (DER) berpengaruh signifikan terhadap return saham pada perusahaan properti dan real estate yang terdaftar di BEI tahun 2013-2015 ?

2. Apakah Net Profit Margin (NPM) berpengaruh signifikan terhadap return saham pada perusahaan properti dan real estate yang terdaftar di BEI tahun 2013- 2015 ?

\section{TINJAUAN PUSTAKA}

\section{Manajemen Keuangan}

Menurut Husnan dan Enny (2006) Manajemen Keuangan menyangkut kegiatan perencanaan, analisis dan pengendalian kegiatan keuangan. Orang yang melaksanakan kegiatan tersebut sering disebut sebagai manajer keuangan. Menurut Fahmi (2012) manajemen keuangan adalah penggabungan dari ilmu dan seni yang membahas, mengkaji dan menganalisa tentang bagaimana seorang manajer keuangan dengan mempergunakan seluruh sumberdaya perusahaan untuk mencari dana, mengelola dana dan membagi dana dengan tujuan mampu memberikan profit atau kemakmuran bagi para pemegang saham dan suistainability (keberlanjutan) usaha bagi perusahaan.

\section{Laporan Keuangan}

Menurut Fahmi (2011) laporan keuangan merupakan suatu informasi yang menggambarkan kondisi suatu perusahaan, dimana selanjutnya itu akan menjadi suatu informasi yang menggambarkan tentang kinerja suatu perusahaan. Menurut Farid dan Siswanto dalam Fahmi (2011) laporan keuangan merupakan informasi yang diharapkan mampu memberikan bantuan kepada pengguna untuk membuat keputusan ekonomi yang bersifat finansial.

\section{Kinerja Keuangan}

Menurut Fahmi (2011) kinerja keuangan adalah suatu analisis yang dilakukan untuk melihat sejauh mana suatu perusahaan telah melaksanakan dengan menggunakan aturan-aturan pelaksanaan keuangan secara baik dan benar. Menurut Harmono (2009) kinerja keuangan umumnya diukur berdasarkan penghasilan bersih (laba) atau sebagai dasar bagi ukuran yang lain seperti imbalan investasi (return on investment) atau penghasilan per saham (earning per share).
Capital Structure and Profitability 
Capital Structure and Profitability

\section{Struktur Modal}

Ada beberapa pengertian struktur modal antara lain:

1. Menurut Halim (2007) struktur modal menunjukkan perimbangan jumlah utang jangka pendek yang bersifat tetap, utang jangka panjang, saham preferen, dan saham biasa. Dalam teori struktur modal dinyatakan mengenai apakah perubahan struktur modal berpengaruh atau tidak terhadap nilai perusahaan, dengan asumsi keputusan investasi dan kebijakan dividen tidak berubah. Apabila ada pengaruhnya, berarti ada struktur modal yang terbaik, tetapi jika tidak ada pengaruhnya, berarti tidak ada struktur modal yang terbaik.

2. Menurut Fahmi (2011) struktur modal merupakan gambaran dari bentuk proporsi finansial perusahaan yaitu antara modal yang dimiliki yang bersumber dari utang jangka panjang dan modal sendiri yang menjadi sumber pembiayaan suatu perusahaan.

3. Menurut Sjahrial (2007) struktur modal merupakan pertimbangan antara penggunaan modal pinjaman yang terdiri dari utang jangka pendek yang bersifat permanen, utang jangka panjang dengan modal sendiri, yang terdiri dari saha preferen dan saham biasa.

Rasio yang digunakan dalam penelitian ini adalah DER (Debt to Equity Ratio). Menurut Desmond Wira (2011) DER Debt to Equity Ratio merupakan perbandingan anatara total hutang (hutang lancar dan hutang jangka panjang) dan modal menunjukkan kemampuan perusahaan untuk memenuhi kewajibannya dengan menggunakan model yang ada. DER dapat dihitung dengan rumus :

\section{Profitabilitas}

$$
\text { Debt to Equity Ratio }=\frac{\text { Total Utang }}{\text { Total Ekuitas }}
$$

Menurut Mamduh dan Hanafi dalam Sulistiawati (2013) kemampuan perusahaan untuk menghasilkan laba dapat diukur dengan menggunakan rasio profitabilitas karena rasio ini mengukur kemampuan perusahaan menghasilkan keuntungan (profitabilitas) pada tingkat penjualan asset dan model saham tertentu. Menurut Brigham dan Houston dalam Sulistiawati (2013) profitabilitas adalah hasil akhir dari sejumlah kebijakan dan keputusan yang dilakukan oleh perusahaan-perusahaan. Menurut Wira (2011) rasio profitabilitas digunakan untuk mengetahui kemampuan perusahaan untuk menghasilkan laba. Rasio yang digunakan dalam penelitian ini adalah NPM (Nett Profit Margin). Menurut Riyanto (2011) NPM adalah rasio yang digunakan untuk menunjukkan kemampuan perusahaan dalam menghasilkan laba bersih setelah dipotong pajak.

$$
\text { Net } \text { Profit Margin }=\frac{\text { Laba Bersih }}{\text { Sales }}
$$

Menurut Harahap (2008) semakin besar rasio ini semakin baik karena dianggap kemampuan perusahaan dalam mendapatkan laba.

\section{Return Saham}

Menurut Ang dalam Ratna (2009) return saham adalah tingkat keuntungan yang dinikmati oleh pemodal atas suatu investasi saham yang dilakukan. Menurut Bodje dalam Ratna (2009) return saham adalah penghasilan yang diperoleh selama periode investasi per sejumlah dana yang diinvestasikan dalam bentuk saham. Return saham dapat dihitung sebagai berikut :

$$
\text { Return saham }=\text { Pt-Pt-1/Pt-1 }
$$

Pt : Harga saham pada periode ke-t

Pt-1 : Harga saham pada periode satu hari sebelumnya (t-1)

\section{METODE PENELITIAN}

Penelitian ini dilakukan di Bogor, dimulai dari pengumpulan landasan teori, sumbersumber data kemudian proses pengolahan data yang dimulai awal Desember 2018 sampai dengan Oktober 2019. Desain penelitian ini menggunakan penelitian kausal 
yaitu penelitian untuk mengetahui pengaruh satu atau lebih variabel bebas (independent variable) terhadap variabel terikat (dependent variable). Variabel bebas dalam penelitian ini terdiri dari Debt To Equity Ratio (DER) dan Net Profit Margin (NPM). Adapun variabel terikat dalam penelitian ini adalah Return Saham. Tujuan dalam penelitian yang bersifat kausal yaitu menguji hipotesis suatu variabel independent terhadap variabel dependent yang dimana data yang dikumpulkan akan di uji.

Populasi dalam penelitian ini adalah perusahaan properti dan real estate yang terdaftar di BEI pada tahun 2013- 2015 yang berjumlah 41 perusahaan dan dengan teknik purposive judgment yaitu teknik pengambilan sampel berdasakan pertimbangan atau kriteria, maka sample yang diambil berjumlah 37 perusahaan. Pengambilan periode data 2013 -2015 didasarkan pertumbuhan industri properti terjadi mulai tahun 2013 dan mulai melambat pada tahun 2015, sehingga fenomena siklus bisnis dalam suatu diharapkan dapat terwakili.

Dalam penelitian ini, sumber data yang digunakan adalah data sekunder. Data sekunder adalah data yang diperoleh atau dikumpulkan oleh peneliti dari berbagai sumber yang telah ada. Data sekunder yang digunakan dalam penelitian ini bersumber dari webside www.idx.co.id dan literature yang berhubungan dengan masalah yang diteliti.

\section{HASIL DAN PEMBAHASAN \\ Statistik Deskriptif}

Hasil analisis deskriptif di atas menunjukkan bahwa jumlah observasi dari penelitian ini adalah 111, penelitian ini menggunakan analisis data panel. Gabungan antara cross section dan time series, dengan cross section sebanyak 37 perusahaan dan time series selama 3 tahun yaitu tahun 2013, 2014 dan 2015. Sehingga diperoleh jumlah observasi sebanyak 111. Pada variabel DER nilai yang terkecil adalah 0.080000 ada pada perusahaan PT Ristia Bintang Mahkotasejati,Tbk tahun 2015 dan nilai tertinggi 2.240000 ada pada perusahaan PT Gowa Makassar Tourism Development,Tbk periode 2013. Pada variabel DER diperoleh nilai rata-rata sebesar 0.799730 dan nilai standar deviasi sebesar 0.486192. Pada variabel NPM nilai yang terkecil adalah -5.363636 ada pada perusahaan PT Bukit Darmo Property,Tbk tahun 2013 dan nilai yang terbesar adalah 92.00000 ada pada perusahaan PT Gowa Makassar Tourism Development,Tbk tahun 2013. Pada variable NPM diperoleh nilai rata-rata sebesar 1.205503 dan nilai standar deviasi adalah sebesar 8.832203. Pada variabel Return Saham nilai yang terkecil adalah -74.85714 ada pada perusahaan PT Gading Development tahun 2013 dan nilai terbesar adalah 1157.576 ada pada perusahaan PT Gowa Makassar Tourism Development,Tbk tahun 2013. Pada variable Return saham diperoleh nilai rata-rata sebesar 22.11561 dan nilai standar deviasi sebesar 120.8857

\section{Uji Stasioneritas}

Dari hasil uji stasioneritas variabel DER, diperoleh nilai probabilitas sebesar 0,0000 $<0,05$ sehingga variable DER memiliki data stasioner. Dari hasil uji stasioneritas variabel NPM, diperoleh nilai probabilitas sebesar $0,0000<0,05$ sehingga variable NPM memiliki data stasioner. Dari hasil uji stasioneritas variabel Return Saham, diperoleh nilai probabilitas sebesar $0,0000<0,05$ sehingga variable Return Saham memiliki data stasioner

\section{Model Regresi Data Panel}

Berdasarkan model Common Effect di atas, diperoleh persamaan sebagai berikut :

Return saham

t-Statistic

Prob. T-hitung

F-statistic

Prob (F-Statistic)

$$
\begin{aligned}
& =0.796306+11.96202 \mathrm{DER}+8.626732 \mathrm{NPM} \\
& =0.075132+18.74456 \mathrm{DER}+0.744142 \mathrm{NPM} \\
& =0.9402+0.0000 \mathrm{DER}+0.4584 \mathrm{NPM} \\
& =192.0354 \\
& =0.000000
\end{aligned}
$$

Capital Structure and Profitability

Berdasarkan model Fixed Effect di atas, diperoleh persamaan sebagai berikut : 
Capital Structure and Profitability

$\underline{24}$
Return Saham

t-Statistic

Prob. T-hitung

F-statistic

Prob (F-Statistic)

Berdasarkan hasil model Random Effect di atas, diperoleh persamaan sebagai berikut :

Return Saham

t-Statistic

Prob. T-hitung

F-statistic

Prob (F-Statistic)
$=91.09403+13.37298$ DER $-106.4104 \mathrm{NPM}$

$=3.611878+17.57882$ DER $-3.393937 \mathrm{NPM}$

$=0.0006+0.0000 \mathrm{DER}+0.001 \mathrm{NPM}$

$=13.29794$

$=0.000000$

$=2.221762+12.01160 * \mathrm{DER}+6.769574 * \mathrm{NPM}$

$=0.214080+19.96163 \mathrm{DER}+0.597796 \mathrm{NPM}$

$=0.8309+0.0000 \mathrm{DER}+0.5512 \mathrm{NPM}$

$=192.4798$

$=0.000000$

\section{Uji Chow}

\begin{tabular}{|c|c|c|c|}
\hline \multicolumn{4}{|c|}{ Redundant Foxed Effects Tests } \\
\hline \multicolumn{4}{|l|}{ Pool: POOL } \\
\hline \multicolumn{4}{|c|}{ Test cross-section foxed effects } \\
\hline Effects Test & Statistic. & d.f. & Prob. \\
\hline Cross-section F & 1.519747 & $(36,72)$ & 0.0663 \\
\hline Cross-section Chi-square & 62.741859 & 36 & 0.0038 \\
\hline
\end{tabular}

\section{Sumber: Hasil Output Eviews 8}

Dari hasil uji chow dapat dilihat bahwa nilai probabilitas sebesar 0,0663 $>0,05$ sehingga H0 diterima maka Common effect adalah model yang paling tepat digunakan dalam penelitian ini.

\section{Analisis Model Regresi Data Panel}

\begin{tabular}{|c|c|c|c|c|}
\hline \multicolumn{3}{|c|}{ Dependent Variable: Return } & & \\
\hline \multirow{2}{*}{\multicolumn{3}{|c|}{$\begin{array}{l}\text { Date: 05/09/17 Time: 19:06 } \\
\text { Sample: } 20132015\end{array}$}} & & \\
\hline & & & & \\
\hline \multicolumn{3}{|c|}{ Included observations: 3} & & \\
\hline \multicolumn{3}{|c|}{ Cross-sections included: 37} & & \\
\hline \multicolumn{4}{|c|}{ Total pool (balanced) observations: 111} & \\
\hline Variable & Coefficient & Std. Error & t-Statistic & Prob. \\
\hline $\mathrm{C}$ & 0.796306 & 10.59879 & 0.075132 & 0.9402 \\
\hline DER & 11.96202 & 0.638160 & 18.74456 & 0.0000 \\
\hline NPM & 8.626732 & 11.59286 & 0.744142 & 0.4584 \\
\hline R-squared & 0.780519 & Mean deper & nit var & 22.11561 \\
\hline Adjusted R-s quared & 0.776455 & S.D. depen & var & 120.8857 \\
\hline S.E. of regression & 57.15542 & Akaike info & erion & 10.95608 \\
\hline Sum squared resid & 352808.2 & Schwarzcri & on & 11.02931 \\
\hline Log likelihood & -605.0625 & Hannan-Qu & criter. & 10.98579 \\
\hline F-statistic & 192.0354 & Durbin-Wats & stat & 2.120396 \\
\hline Prob(F-statistic) & $0.0 \overline{0} 0 \overline{0} 0 \overline{0}$ & & & \\
\hline
\end{tabular}

\section{Sumber: Hasil Output Eviews 8}

Dari hasil estimasi dengan menggunakan model Common Effect dapat dibentuk persamaan sebagai berikut :

Return Saham $=0.796306+11.96202 \mathrm{DER}+8.626732 \mathrm{NPM}$ 
Persamaan diatas menggambarkan hubungan antara masing-masing variabel independen terhadap variabel dependen yaitu:

1. Nilai koefisien regresi DER sebesar 11.96202 artinya apabila DER mengalami kenaikan sebesar 1 sedangkan variabel lainnya dianggap konstan, maka Return Saham mengalami kenaikan sebesar 11.96202 .

2. Nilai koefisien regresi NPM sebesar 8.626732 artinya apabila NPM mengalami kenaikan sebesar 1 sedangkan variabel lainnya dianggap konstan, maka Return Saham mengalami kenaikan sebesar 8.62673

\section{Uji Koefisien Determinasi $\left(R^{2}\right)$}

Berdasarkan tabel $4.10, R$-Square $\left(\mathrm{R}^{2}\right)$ sebesar 0.780519 . Dengan demikian variabel DER dan NPM berpengaruh signifikan terhadap Return Saham sebesar 78,1\% sedangkan $21,9 \%$ dipengaruhi faktor - faktor lain yang tidak diteliti dalam penelitian ini.

\section{Pengujian Model Regresi Data Panel (Uji F)}

Dari tabel di atas menunjukkan F-Statistic $192.0354>\mathrm{F}$ Tabel 3,26, maka $\mathrm{H}_{0}$ ditolak dan $\mathrm{H}_{1}$ diterima, artinya secara bersama-sama ada pengaruh variabel independen terhadap variabel dependen.

\section{Analisis Koefisien Regresi Data Panel (Uji t)}

Nilai koefisien konstanta adalah 7,549200 dan nilai koefisien DER adalah 12,08327 yang menjelaskan besar pengaruh DER terhadap return saham sebesar 12,08327 dengan tingkat derajat kepercayaan memiliki probabilitas $0,00<0,05$ maka dikatakan Ho ditolak dan H1 diterima. Maka dapat disimpulkan DER berpengaruh positif dan signifikan terhadap return saham.

Nilai koefisien konstanta adalah -29.15294 dan nilai koefisien NPM adalah 64.10736 yang menjelaskan besar pengaruh NPM terhadap return saham sebesar 64.10736 dengan tingkat derajat kepercayaan memiliki probabilitas $0,0063<0,05$ maka dikatakan Ho ditolak dan H1 diterima. Maka dapat disimpulkan NPM berpengaruh positif dan signifikan terhadap return saham.

\section{PENUTUP}

\section{Kesimpulan}

Berdasarkan penelitian yang dilakukan mengenai pengaruh struktur modal dan profitabilitas terhadap return saham pada perusahaan properti dan real estate yang terdaftar di BEI tahun 2013-2015, maka dapat ditarik kesimpulan sebagai berikut :

1. Berdasarkan hasil Uji $t$, diperoleh hasil bahwa DER berpengaruh positif dan signifikan terhadap return saham

2. Berdasarkan hasil Uji t, diperoleh hasil bahwa NPM berpengaruh positif dan signifikan terhadap return saham

\section{Rekomendasi}

1. Bagi investor, semua rasio keuangan yang menjadi variabel penelitian ini dapat dijadikan parameter yang baik untuk memprediksi perubahan return saham.

2. Rasio DER dapat digunakan untuk menjelaskan return saham perusahaan property dan real estate, bahwa untuk menjalankan sebuah perusahaan memang dibutuhkan hutang dan ketika rasio ini meningkat dapat menjadi pertimbangan bagi investor dalam menganalisis kinerja perusahaan yang mempengaruhi return.

3. Rasio NPM dapat digunakan untuk menjelaskan return saham perusahaan property dan real estate, bahwa semakin tinggi rasio ini maka kemampuan perusahaan menghasilkan keuntungan semakin besar dan dapat menjadi pertimbangan bagi investor dalam menganalisis kinerja perusahaan yang mempengaruhi return. 
Capital Structure and Profitability
4. Penelitian ini juga diharapkan dapat digunakan sebagai tambahan refrensi bagi penelitian selanjutnya yang akan dating untuk dikembangkan dan diperbaiki.

\section{DAFTAR PUSTAKA}

[1] Arisandi, Meri, 2014. Pengaruh ROA, DER, CR, Inflasi dan Kurs Terhadap Return Saham (Studi Kasus Industri Makanan dan Minuman Yang Terdaftar di BEI Periode 2008-2012). Jurnal Dinamika Manajemen Vol.2 No.1 ISSN: 2355-8148. Hal: 34-46.

[2] Ariyanti, Ika Ajeng dan Suwitho. 2016. Pengaruh CR, TATO, NPM DAN ROA Terhadap Return Saham. Jurnal Ilmu dan Riset Manajemen : Vol. 5, No. 4 ISSN : 2461-0593. Hal : 1-16.

[3] Ayu, Syarifah. 2013. Analisis Pengaruh Rasio Profitabilitas dan Solvabilitas Terhadap Return Saham Pada Perusahaan Real Estate dan Properti Yang Terdaftar di BEI. Jakarta: Skripsi Program Studi Akuntasi Universitas Mercu Buana.

[4] Caesario, Emanuel B., 2016. Survei BI Pertumbuhan Properti Kuartal IV 2015 Melambat.https://ekonomi.bisnis.com/read/20160215/107/519116/survei-bipertumbuhan-properti-kuartal-iv-2015-melambat. Diakses pada 10 Januari 2020.

[5] Candradewi, Reina Made. 2016. Pengaruh Kinerja Keuangan Terhadap Return Saham Pada Perusahaan LQ45 di BEI : Analisis Regresi Data Panel. E-Jurnal Ekonomi dan Bisnis Universitas Udayana 5.7 (2016): 2091-2122. Hal: 2091-2122.

[6] Fahmi, Irham. 2011. Analisis Kinerja Keuangan. Edisi 1. Bandung: Alfabeta.

[7] Fahmi, Irham. 2012. Pengantar Pasar Modal. Edisi 1. Bandung: Alfabeta.

[8] Ferdinand, Augusty. 2014. Metode Penelitian Manajemen Pedoman Penelitian Untuk Penulisan Skripsi Tesis Dan Disertasi Ilmu Manajemen. Edisi 5. Badan Penerbit Universitas Diponegoro.

[9] Fittri. 2013. Analisis Pengaruh Faktor Fundamental Perusahaan Terhadap Return Saham Perusahaan Manufaktur. Jurnal Sosial Humaniora Vol.4 No.1 ISSN 2087-4928. Hal: $1-10$.

[10] Gujarati, D.N. 2012. Dasar-dasar Ekonometrika. Edisi Kelima. Buku Kedua. Jakarta: Salemba Empat.

[11] Ghi, Tran Nha. 2015. The Impact of Capital Structure and Financial Performance on Stock Return of The Firms in Hose. International Journal of Information Research and Review Vol. 2, Issue, 06. PP: 734-737.

[12] Halim, Abdul. 2007. Manajemen Keuangan Bisnis. Bogor: Ghalia Indonesia. Harahap, Sofyan Syafri. 2008. Analisis Kritis Atas Laporan Keuangan. Jakarta: Raja Grafindo Persada.

[13] Harjito, Agus dan Martono. 2007. Manajemen Keuangan. Yogyakarta: Ekonisia.

[14] Harmono. 2009. Manajemen Keuangan Berbasis Balanced Scorecard (Pendekatan Teori, Kasus, dan Riset Bisnis). Jakarta: Bumi Aksara.

[15] Hendra, Lukas. 2017. Bisnis Properti Masih Dibayangi Sikap Wait And See. http://properti.bisnis.com/read/20170801/107/676785/bisnis-properti-masihdibayangi-sikap-wait-and-see. Diakses pada 12 Januari 2020.

[16] Husnan, Suad dan Eny Pudjiastuti. 2006. Dasar-dasar Manajemen Keuangan. Edisi Kelima. Yogyakarta: UPP STIM YKPN.

[17] Ikatan Akuntan Indonesia. 2009. Standar Akuntansi Keuangan. Jakarta: Salemba Empat.

[18] Jogiyanto, H.M., 2010. Teori Portofolio dan Analisis Investasi. Edisi Ketujuh. BPFE. Yogyakarta.

[19] Kasmir. 2014. Analisis Laporan Keuangan. Edisi Satu. Cetakan Ketujuh. Jakarta : PT Raja Grafindo Persada.

[20] Kembauw, E., Munawar, A., Purwanto, M.R., Budiasih, Y. and Utami, Y., 2020. Strategies of Financial Management Quality Control in Business. 
[21] Khan, Wajid., Naz, Arab., Khan, Madiha., Khan, Waseem Khan Qaiser., \& Shabeer Ahmad. 2013. The Impact of Capital Structure and Financial Performance on Stock Return A Case of Pakistan Textile Industry. ISSN 1990-9233. Hal: 289-295.

[22] Nachrowi D. dan Hardius Usman. 2006. Pendekatan Populer dan Praktis Ekonometrika untuk Analisis Ekonomi dan Keuangan. Jakarta: Lembaga Penerbit FE UI.

[23] Nidianti, Imba Putu. 2013. Pengaruh Faktor Internal dan Ekstrnal Perusahaan Terhadap Return Saham Food and Beverages di Bursa Efek Indonesia. E-Jurnal Akuntansi Universitas Udayana 5.1 ISSN: 2302-8556. Hal: 130-146.

[24] Nurhakim, Anistia S., Yunita, Irni., \& Aldilla Iradianty. 2016. The Effect of Profitability and Inflation on Stock Return at Pharmaceutical Industries at BEI In The Period of 2011-2014. ISSN: 2205-6033. Hal: 202-210.

[25] Prastowo, Dwi. 2011. Analisis Laporan Keuangan. Edisi Ketiga. Yogyakarta: UPP STIM YKPN.

[26] Purba, J.H.V., Ratodi, M., Mulyana, M., Wahyoedi, S., Andriana, R., Shankar, K. and Nguyen, P.T., 2019. Prediction Model in Medical Science and Health Care.

[27] Purba, J.H.V., 2017. The analysis of European Union's vegetable oil consumption:" will the European Parliament Resolution Halt the Consumption of Crude Palm Oil in the European Union in the future?". International Journal of Applied Business and Economic Research, 15, p.19.

[28] Purwitajati, Endah dan I Made Pande Dwiana Putra. 2016. Pengaruh Debt To Equity Ratio Pada Return Saham Dengan Ukuran Perusahaan Sebagai Pemoderasi. E-Jurnal Akuntansi Universitas Udayana Vol.15.2. Mei (2016): 1086-1114 ISSN: 2302-8556. Hal: 1086-1114.

[29] Putri, Handayani Wuri. 2013. Pengaruh Kinerja Keuangan Terhadap Return Saham Pada Perusahaan Manufaktur Sub Sektor Makanan dan Minuman di Bursa Efek Indonesia. Jakarta: Skripsi Falkutas Ekonomi dan Bisnis Universitas Mercu Buana.

[30] Ratna, Prihantini. 2009. Analisis Pengaruh Inflasi, Nilai Tukar, ROA, DER, dan CR Terhadap Return Saham. Semarang: Tesis Program Magister Manajemen Pascasarjana Universitas Dipenogoro.

[31] Riyanto Bambang. 2011. Dasar-dasar Pembelanjaan Perusahaan. Edisi Keempat. Yogyakarta: BPFE

[32] Setiyono, Erik dan Lailatul Amanah. 2016. Pengaruh Kinerja Keuangan dan Ukuran Perusahaan Terhadap Return Saham. Jurnal Ilmu dan Riset Akuntansi : Vol. 5, No. 5 ISSN : 2460-0585. Hal: 1-17.

[33] Situmorang, Paulus. 2008. Pengantar Pasar Modal. Edisi Pertama. Jakarta : Mitra Wacana Media.

[34] Sulistiawati, Eka. 2013. Pengaruh Perputaran Aset Tetap, Perputaran Persediaan dan Size Terhadap Profitabilitas. Jakarta: Skripsi Program Studi Akuntasi Universitas Mercu Buana.

[35] Suryati. 2013. Pengaruh ROA, Current Ratio dan TATO Terhadap Return Saham Pada Saham Syariah (Studi Empiris Pada Kelompok Saham Jakarta Islamic Index). Jakarta: Skripsi Program Studi Akuntasi Universitas Mercu Buana.

[36] Susilowati, Yeye dan Tri Turyanto. 2011. Reaksi Signal Rasio Profitabilitas dan Rasio Solvabilitas Terhadap Return Saham Perusahaan. Dinamika Keuangan dan Perbankan Vol.3 No.1 ISSN :1979-4878. Hal: 17-37.

[37] Sjahrial, Dermawan. 2007. Pengantar Manajemen Keuangan. Edisi Kedua. Jakarta: Mitra Wacana Media.

[38] Van der Schaar, R.M.A., 2016. Analisis Pasar Properti Indonesia Overview \& Kepemilikan Asing. http://www.indonesia-investments.com/id/berita/kolomberita/analisis-pasar-properti-indonesia-overview-kepemilikanasing/item5728?.

Diakses pada 10 Januari 2020. 
Capital Structure and Profitability
[39] Widiyanto, Agus Mikha. (2013). Statistika Terapan Konsep \& Aplikasi SPSS/LISREL Dalam Penelitian Pendidikan, Psikologi \& Ilmu Sosial Lainnya. Jakarta : PT Alex Media Komputindo.

[40] Wira, Desmond, 2011. Analisis Fundamental saham. Edisi pertama. Jakarta: Exced. 